\title{
OPTIMISATION OF FRUCTOSE PRODUCTION BY ENZYMATIC HYDROLYSIS OF CHICORY FRUCTANS
}

\author{
Octavian Baston and Octavian Barna* \\ ${ }^{1}$ Department of Food Science and Applied Biotechnology, Faculty of Food Science and Engineering, Dunarea de Jos \\ University, 111 Domneasca Street, 800201, Galati, Romania. \\ *Corresponding author's e-mail: octavian.barna@yahoo.com
}

\begin{abstract}
The response surface method and Box-Behnken design were used to determine the effect of inulinase concentration, $\mathrm{pH}$, hydrolysis temperature and time on chicory fructans. Enzyme concentration between 8 and $80 \mathrm{INU} \cdot \mathrm{g}^{-1}$, temperatures of $50{ }^{\circ} \mathrm{C}$, $57.5^{\circ} \mathrm{C}$ and $65^{\circ} \mathrm{C}$, pH of 4.0 to 6.5 and hydrolysis time between 1 and 96 hours were studied to establish the optimal conditions of chicory fructans hydrolysis. Enzyme concentration, hydrolysis time and $\mathrm{pH}$ were the most important variables which have positive effects on enzymatic hydrolysis. The maximum quantity of fructose released from substrate is produced when the concentration of enzyme is $44 \mathrm{INU} / \mathrm{g}$, for a temperature of $65^{\circ} \mathrm{C}$, a hydrolysis time of 48.5 hours and a pH of 6.5 . The minimum fructose amount was produced at an enzyme concentration of $44 \mathrm{INU} \cdot \mathrm{g}^{-1}$, temperature of $57.5^{\circ} \mathrm{C}$, the hydrolysis time of 1 hour and $\mathrm{pH}$ of 4.0 .

Keywords: Inulinase, chicory flour, response surface method, fructose.
\end{abstract}

\section{INTRODUCTION}

Fructose can be found in plant foods in a variety of forms including the free monosaccharide form or polymerized to form fructans. Fructans with a short chain length (degree of polymerization of 2-9 units) are known as fructooligosaccharides (FOS), and those with a longer chain (degree of polymerization over 10 units) are termed inulins (Muir et al., 2007).

Inulin function as a reserve carbohydrate in plants such as Jerusalem artichoke, dahlia and chicory, being found in smaller amounts in garlic and onion (Chi et al., 2011; Singh and Gill, 2006).

Inulins are a group of naturally occurring polysaccharides that can be hydrolysed by two types of inulinases: exo-inulinases ( $\beta$-D-fructanfructohydrolase, EC 3.2.1.80) and endoinulinases (2,1- $\beta$-D-fructanfructanohydrolase, EC 3.2.1.7). Exo-inulinases split the terminal units of the inulin with a lower degree of polymerization and liberates fructose. Endoinulinases hydrolyse inulin by breaking the bonds between fructose units that are located away from the ends of the polymer network, to produce oligosaccharides.

Inulinases are enzymes that have different catalytic properties: molecular weight, optimum $\mathrm{pH}$ and temperature of action, stability, according to the sources. The inulinase produced by Aspergillus niger has optimum catalytic properties at $\mathrm{pH}$ of $4.4-5.0$ and temperature of $40{ }^{\circ} \mathrm{C}$ (Chen et al., 2012; Pandey et al., 1999).

Fructose is a simple carbohydrate found naturally in plants (fruits and vegetables). Because fructose have a higher power of sweetening compared to glucose, it is use as food sweetener. The fructose is important for diabetic products because replace sucrose in various foods and beverages. Fructose as fructose syrup is use in the food industry for the production of carbonated soft drinks, fruit beverages, yogurts, ice cream, bakery goods, puddings, dairy products and baby food etc. Also it is used in pharmaceutical industry as excipient in pharmaceutical formulations (tablets, syrups, and solutions) (Lima et al., 2011). So, the production of fructose is very important for human nutrition and health. Since 1989 fructose syrups was produced by hydrolyzing the inulin extracted from Jerusalem artichoke, chicory, dahlia, yacon (Hodgins et al., 2014).

Response surface methodology has been successfully used to model and optimize biochemical and biotechnological processes related to food systems (de Lima et al. 2010). Optimization of process by statistical experimental designs is very useful, as it helps in understanding the interactions among the process parameters at varying levels and in calculating an optimal level of each parameter for the maximal product yield (Trivedi et al., 2012). Both the Central Composite Design (CCD) and the Box-Benken (BB) design can be utilized, but they have different structures, and if the experimental region is such that extreme points are a problem, then there are some advantages to the BB. Compared to CCD, the $\mathrm{BB}$ design requires fewer experimental runs and less time. Compared to the conventional processes of formulating and optimization, BB provides a far more effective and costeffective technique.

The aim of the present study was to establish the optimal conditions for hydrolysis of fructans from chicory flour by 
using a commercial inulinase, based on statistical analysis by applying the response surface methodology.

\section{MATERIALS AND METHODS}

Materials: The present study has used inulinase Novozym 960 from Novozymes A/S, Denmark, a liquid with a density of $1.17 \mathrm{~g} \cdot \mathrm{ml}^{-1}$ and an activity of $400 \mathrm{INU} \cdot \mathrm{g}^{-1}$ at $\mathrm{pH}=6$. One INU (inulinase units) is equivalent to the amount of enzyme that produces $1 \mu$ mole reducing carbohydrate per minute under the conditions of $50{ }^{\circ} \mathrm{C}$ and $\mathrm{pH}=4.70$. The enzyme is produced by an Aspergillus niger strain.

The chicory roots were purchased from a local producer (Hofigal, Romania). They were washed, sliced, dried using Alpha 1-4 LD Plus freeze-dryer (Martin Christ $\mathrm{GmbH}$, Germany) and transformed into flour by grinding with VC2011 grinder (Victronic, PRC).

Methods: The $\mathrm{pH}$ was determined using digital $\mathrm{pH}$-meter S20 (Mettle Toledo, Spain) according to AOAC (2003). The dry matter percentage was determined by a standard drying method (AOAC, 2003) in ED 115Loven (Binder GmbH, Germany) at $105{ }^{\circ} \mathrm{C}$ to constant mass. The protein amount was estimated by Kjeldahl method as the total nitrogen and multiplied by a factor of 5.40 (AOAC, 2003) and determined using MBC-6 Kjeldahl digestor (Raypa, Spain) and automatic steam distilling unit UDK $130 \mathrm{D}$ (Velp Scientifica, Italy). The lipid content was determined by the Soxhlet method (AOAC, 2003) using SER 148/6 automatic extractor (Velp Scientifica, Italy). The ash content was determined by the slow combustion method at $650{ }^{\circ} \mathrm{C}$ for $2 \mathrm{~h}$ (AOAC, 2003) using FB 1300 furnace (Cole-Palmer, USA). The fructose amount was estimated by 3.5-dinitrosalicylic acid method according to Miller method (Miller, 1959) using UV-Vis spectrophotometer Jenway 6505 (Bibby Scientific Ltd., UK). A calibration curve was set at $535 \mathrm{~nm}$ using standard fructose solutions. Fructans (FOS and inulin) was determined using Fructan Assay Procedure for the measurement of FructoOligosaccharides (FOS) and Fructan Polysaccharide (Megazyme International, Ireland), according to AOAC Method 999.03.

Inulinase assay: A quantity of $2 \mathrm{~g}$ of chicory flour was mixed using V1 Plus mixer (Boeco, Germany) with $100 \mathrm{ml}$ phosphate-citrate buffer ( $\mathrm{pH}=4.00,5.25$ or 6.50 ), according to Table 2, in Dewar $300 \mathrm{ml}$ tubes. The $\mathrm{pH}$ was checked with the $\mathrm{pH}$-meter (Mettler Toledo, UK). 8.0 to $80.0 \mathrm{INU} \cdot \mathrm{g}^{-1}$ were added to the inulin solution and the mixtures were incubated at different temperatures according with the experimental design: $50{ }^{\circ} \mathrm{C}$ and $65{ }^{\circ} \mathrm{C}$, respectively, using Stericell 111 oven (MMM Münchener Medizin Mechanik $\mathrm{GmbH}$, Germany) and at $57.5{ }^{\circ} \mathrm{C}$ using BF400 incubator (Binder $\mathrm{GmbH}$, Germany) for 1 to 96 hours. The enzymatic reaction was stopped by boiling the samples at $100 \pm 2^{\circ} \mathrm{C}$ for 10 minutes on a water bath. All the samples were made in triplicate.
Statistical analysis: The levels of the significant parameters and the interaction effects between various parameters, which significantly influence the enzymatic hydrolysis, were analysed and optimized using response surface methodology. Expert-Design 8 software (Stat-Ease, Inc., Minneapolis, USA) was used for the experimental design, data analysis, and quadratic model building and variables interaction graphs building.

A 4-factor Box-Behnken design, with 3 levels for each factor, was used for design. The particularity of this type of design is that the extreme levels are not included in the design, so the experiments combine only 3 levels of each design variable. The mid-levels of some variables are combined with extreme levels of others (Esbensen, 2010). A total of 27 experiments were necessary to estimate the coefficients of the model.

The quadratic model used by software for describing the tested experimental conditions is a second degree polynomial equation (eq. 1).

$\mathrm{Y}=\mathrm{b}_{0}+\mathrm{b}_{1} \mathrm{~A}+\mathrm{b}_{2} \mathrm{~B}+\mathrm{b}_{3} \mathrm{C}+\mathrm{b}_{4} \mathrm{D}+\mathrm{b}_{5} \mathrm{AB}+\mathrm{b}_{6} \mathrm{AC}+\mathrm{b}_{7} \mathrm{BC}+$

$b_{8} A D+b_{9} B D+b_{10} C D+b_{11} A^{2}+b_{12} B^{2}+b_{13} C^{2}+b_{14} D^{2}$ eq. (1) where $\mathrm{Y}$ is the response (dependent variable), or the amount of fructose released from fructans hydrolysis; A, B, C and D are independent variables, $b_{0}$ is the intercept and $b_{1}$ to $b_{14}$ are the regression coefficients.

\section{RESULTS AND DISCUSSION}

The chicory flour was analysed and the physico-chemical characteristics are presented in Table 1. The amount of protein, ash and fructans was higher due to the high amount of dry matter of chicory flour. The $\mathrm{pH}$ value of the flour was moderately acid and the amount of free fructose was low. Due to the high value of fructans, the studied chicory flour can be enzymatic treated to produce high amounts of fructose that can be used in food and pharmaceutical industry. Our physico-chemical values for chicory flour are according to the values found by Wang and Cui (2011).

Table 1. Chicory flour characteristics (mean \pm standard deviation).

\begin{tabular}{lc}
\hline & Characteristics \\
\hline $\mathrm{pH}$ & $5.77 \pm 0.12$ \\
Dry matter (\%) & $95.04 \pm 1.26$ \\
Protein (g/100 g d.w.) & $9.20 \pm 0.50$ \\
Lipid (g/100 g d.w.) & $1.13 \pm 0.07$ \\
Ash (g/100 g d.w.) & $6.08 \pm 0.37$ \\
Fructose (g/100 g d.w.) & $3.90 \pm 0.14$ \\
Fructans (g/100 g d.w.) & $66.50 \pm 2.01$ \\
\hline
\end{tabular}

The influence of four independent variables; concentration of enzyme, temperature, hydrolysis time and $\mathrm{pH}$, upon enzymatic hydrolysis was investigated in order to increase the yield of reducing sugar released from substrate. 
The matrix of variation of independent variables is presented in Table 2. Starting from biochemical characteristics of the inulinase used in this study, in Table 2 we have chosen the limits for the independent variables. By applying the response surface method we analyzed the main factors (independent variables) that influence the hydrolysis process: concentration of enzyme, temperature, hydrolysis time and $\mathrm{pH}$. Response surface method has been used to examine the relationships between the factors (the independent variables) which influence the hydrolysis of fructans and the result produced (the response variable).

Table 2. The independent variables and their levels for the Box-Behnken design.

\begin{tabular}{lcccc}
\hline Independent & Code & \multicolumn{3}{c}{ Levels of variations } \\
\cline { 3 - 5 } variables & & -1 & 0 & +1 \\
\hline Concentration of & $\mathrm{A}$ & 8.00 & 44.00 & 80.00 \\
enzyme, $\left(\mathrm{INU} \cdot \mathrm{g}^{-1}\right)$ & & & & \\
Temperature $\left({ }^{\circ} \mathrm{C}\right)$ & $\mathrm{B}$ & 50.00 & 57.50 & 65.00 \\
Hydrolysis time (h) & $\mathrm{C}$ & 1.00 & 48.50 & 96.00 \\
$\mathrm{pH}$ & $\mathrm{D}$ & 4.00 & 5.25 & 6.50 \\
\hline
\end{tabular}

The response variable, as presented in Table 3 is the fructose amount produced by enzymatic hydrolysis of fructans. For this purpose, we used a Box-Behnken design (Table 3).

As it can be seen in Table 3, a fructose yield between 0.144 to $0.530 \mathrm{~g}$ fructose $\mathrm{g}^{-1}$ chicory flour was produced by enzymatic hydrolysis of chicory fructans by the commercial inulinase. The maximum quantity of fructose released from substrate was produced when the concentration of enzyme was $44 \mathrm{INU} / \mathrm{g}$, for a temperature of $65{ }^{\circ} \mathrm{C}$, a hydrolysis time of 48.5 hours and a $\mathrm{pH}$ of 6.5 . The minimum fructose amount of $0.144 \mathrm{~g} \cdot \mathrm{g}^{-1}$ chicory flour, was produced at an enzyme concentration of $44 \mathrm{INU} \cdot \mathrm{g}^{-1}$, temperature of $57.5^{\circ} \mathrm{C}$, the hydrolysis time of 1 hour and $\mathrm{pH}$ of 4.0. The small amount of fructose is due to the reduced $\mathrm{pH}$ and short hydrolysis time.

Sirisansaneeyakul (2007), using inulinases of Aspergillus niger TISTR 3570, and the inulin hydrolysis parameters like inulin concentration of $100 \mathrm{~g} \cdot \mathrm{l}^{-1}$, temperature of $40{ }^{\circ} \mathrm{C}, \mathrm{pH}=$ 4.5 and after 25 hours of hydrolysis, obtained a fructose quantity of $72.3 \mathrm{~g} / 100 \mathrm{~g}$ of chicory root pure inulin. In this case, the low fructose yield produced can be due to the reduced hydrolysis time.

Cruz (1998), using an inulinase from Aspergillus niger-245, hydrolysis $\mathrm{pH}$ between 4 and 4.5 , at $60{ }^{\circ} \mathrm{C}$ and over 60 hours of pure chicory inulin hydrolysis, have produced a fructose yield of $90 \%$. Comparing it with our experimental data, it can be concluded that the enzymatic inulin hydrolysis parameters are influenced by the type of the Aspergillus niger strain used and by the degree of enzyme purification.

The statistical significance of the model equation was checked using the F-test analysis of variance (ANOVA) (Table 4).
Table 3. The experimental design of the enzymatic hydrolysis of chicory fructans.

\begin{tabular}{cccccc}
\hline Run & \multicolumn{3}{l}{ Independent variable variation } & $\begin{array}{c}\text { Fructose amount } \\
\text { (g· } \mathbf{- 1} \text { chicory } \\
\text { flour) }\end{array}$ \\
\hline 1 & $\mathbf{A}$ & $\mathbf{B}$ & $\mathbf{C}$ & $\mathbf{D}$ & 0.144 \\
2 & 0 & 0 & -1 & -1 & 0.216 \\
3 & 0 & 0 & +1 & -1 & 0.336 \\
4 & 0 & 0 & -1 & +1 & 0.414 \\
5 & 0 & 0 & +1 & +1 & 0.330 \\
6 & -1 & -1 & 0 & 0 & 0.220 \\
7 & -1 & -1 & 0 & 0 & 0.222 \\
8 & +1 & +1 & 0 & 0 & 0.400 \\
9 & -1 & 0 & 0 & -1 & 0.510 \\
10 & +1 & 0 & 0 & -1 & 0.402 \\
11 & -1 & 0 & 0 & +1 & 0.390 \\
12 & +1 & 0 & 0 & +1 & 0.480 \\
13 & 0 & -1 & -1 & 0 & 0.318 \\
14 & 0 & +1 & -1 & 0 & 0.350 \\
15 & 0 & -1 & +1 & 0 & 0.240 \\
16 & 0 & +1 & +1 & 0 & 0.342 \\
17 & 0 & -1 & 0 & -1 & 0.414 \\
18 & 0 & +1 & 0 & -1 & 0.504 \\
19 & 0 & -1 & 0 & +1 & 0.408 \\
20 & 0 & +1 & 0 & +1 & 0.530 \\
21 & -1 & 0 & -1 & 0 & 0.306 \\
22 & +1 & 0 & -1 & 0 & 0.252 \\
23 & -1 & 0 & +1 & 0 & 0.438 \\
24 & +1 & 0 & +1 & 0 & 0.456 \\
25 & 0 & 0 & 0 & 0 & 0.485 \\
26 & 0 & 0 & 0 & 0 & 0.516 \\
27 & 0 & 0 & 0 & 0 & 0.250 \\
\hline & & & & &
\end{tabular}

The ANOVA of quadratic regression model (Table 4) demonstrates that the model is highly significant, as it is evident from the Fisher's F-test with a very low probability value (p-value $<0.0001$ ). The model F-value of 51.318 indicates that the predicted model is suitable for good fitting. The suitability of the model's fit was checked by the determination coefficient $\left(\mathrm{R}^{2}\right)$ of 0.983 (or 98.3\%). Adjusted $\mathrm{R}^{2}$ is a modification of $\mathrm{R}^{2}$ that adjusts for the number of explanatory terms in a model. The adjusted $\mathrm{R}^{2}$ increases only if the new term improves the model more than it would be expected by chance. The adjusted $\mathrm{R}^{2}$ was 0.964 . The high coefficient $\mathrm{R}^{2}$ value shows the applicability of the regression model between the ranges of the variables included. This correlation is also confirmed by the plot presented in Fig.1.

The coefficient of variation (CV\%) was 5.58. Such relatively low value of $\mathrm{CV} \%$ indicates a better precision and reliability of the experiments carried out.

The adequate precision was 23.04. It measures the signal to noise ratio and this ratio was greater than 4 as it indicates an adequate signal. The F-Value of the lack of fit was 2.733 meaning that the model is significant. The high value of the 
Table 4. Analysis of variance (ANOVA) for the quadratic model.

\begin{tabular}{lcrrrr}
\hline Source & $\begin{array}{c}\text { Sum of } \\
\text { squares }\end{array}$ & $\begin{array}{c}\text { Degrees of } \\
\text { freedom }\end{array}$ & $\begin{array}{r}\text { Mean } \\
\text { squares }\end{array}$ & F-value & p-value \\
\hline (Enzyme concentration) A & 0.0536 & 1 & 0.05360 & 128.744 & $<0.0001$ \\
(Temperature) B & 0.0102 & 1 & 0.01021 & 24.520 & 0.0003 \\
(Hydrolysis time) C & 0.1302 & 1 & 0.13021 & 312.750 & $<0.0001$ \\
(pH) D & 0.0022 & 1 & 0.00219 & 5.253 & 0.0408 \\
(Enzyme concentration X Temperature) AB & 0.0066 & 1 & 0.00656 & 15.759 & 0.0019 \\
(Enzyme concentration X Hydrolysis time) AC & 0.0006 & 1 & 0.00058 & 1.384 & 0.2623 \\
(Temperature X Hydrolysis time) BC & 0.0001 & 1 & 0.00014 & 0.346 & 0.5674 \\
(Enzyme concentration X pH) AD & 0.0056 & 1 & 0.00563 & 13.511 & 0.0032 \\
(Temperature X pH) BD & 0.0015 & 1 & 0.00152 & 3.653 & 0.0801 \\
(Hydrolysis time X pH) CD & 0.0001 & 1 & 0.00014 & 0.346 & 0.5674 \\
(Enzyme concentration X Enzyme concentration) A A $^{2}$ & 0.0418 & 1 & 0.04177 & 100.333 & $<0.0001$ \\
(Temperature X Temprature) B & 0.0060 & 1 & 0.00599 & 14.376 & 0.0026 \\
(Hydrolysis time X Hydrolysis time) C ${ }^{2}$ & 0.0232 & 1 & 0.02323 & 55.801 & $<0.0001$ \\
(pH X pH) D & 0.0687 & 1 & 0.06871 & 165.025 & $<0.0001$ \\
Quadratic Model & 0.2991 & 14 & 0.02137 & 51.318 & $<0.0001$ \\
Residual (error) & 0.0050 & 12 & 0.00042 & - & - \\
Pure Error & 0.0003 & 2 & 0.00017 & - & - \\
Corr. total & 0.3041 & 26 & - & - & - \\
Lack of fit & 0.0047 & 10 & 0.00047 & 2.733 & 0.2975 \\
R-squared & & & & & 0.983 \\
Adj-squared & & & & & 0.964 \\
Coef. of variation (CV\%) & & & & & 5.580 \\
Adeq. Precision & & & & & 23.040 \\
\hline
\end{tabular}

coefficient of determination shows the applicability of the regression model between the ranges of variables included.

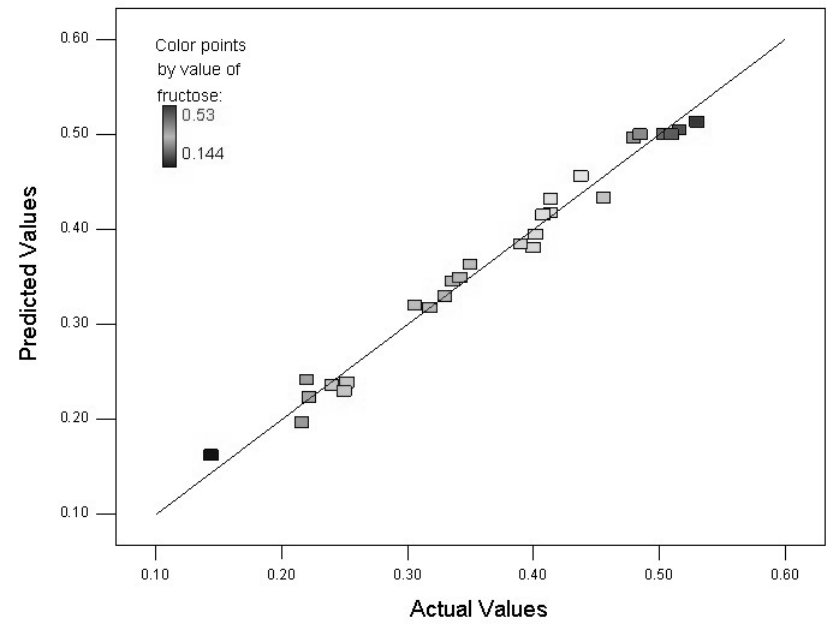

Figure 1.Plot of predicted and the experimental values for fructose production.

A p-value lower than 0.050 indicates that the model terms are significant. In this case the enzyme concentration, the temperature, the hydrolysis time, the $\mathrm{pH}$, the interaction between enzyme concentration and temperature, the interaction between enzyme concentration and $\mathrm{pH}$, the interaction between enzyme concentration and enzyme concentration, the interaction between temperature and temperature, the interaction between hydrolysis time and hydrolysis time and the interaction between $\mathrm{pH}$ and $\mathrm{pH}$ are significant model terms.

Table 5. Coefficient values for the quadratic model.

\begin{tabular}{lc}
\hline Factors & Coefficient \\
\hline Intercept & 0.499 \\
(Enzyme concentration) A & 0.066 \\
(Temperature) B & -0.029 \\
(Hydrolysis time) C & 0.104 \\
(pH) D & 0.0135 \\
(Enzyme concentration · Temperature) AB & 0.0405 \\
(Enzyme concentration · pH) AD & 0.006 \\
(Enzyme concentration · Enzyme & -0.088 \\
concentration) A & -0.033 \\
(Temperature $\cdot$ Temperature) $\mathrm{B}^{2}$ & -0.066 \\
(Hydrolysis time $\cdot$ Hydrolysis time) $\mathrm{C}^{2}$ & -0.113 \\
$(\mathrm{pH} \cdot \mathrm{pH}) \mathrm{D}^{2}$ & \\
\hline
\end{tabular}

According to the parameters from the coefficient values for the quadratic model (Table 5), it can be observed that the hydrolysis time has the greatest influence on the fructose production by enzymatic hydrolysis due to its higher 
coefficient value. Then, in decreasing order, the concentration of enzyme, the interaction between enzyme concentration and temperature, the $\mathrm{pH}$, and the interaction between enzyme concentration and $\mathrm{pH}$ are important factors that contribute to the increase of the amount of fructose. Due to the negative values, the temperature and all the squared variables of the model revealed a reduction in the amount of fructose production.

After the analysis of variance the regression equation 1 becomes:

$$
\begin{gathered}
\mathrm{Y}=0.499+0.066 \mathrm{~A}-0.029 \mathrm{~B}+0.104 \mathrm{C}+0.013 \mathrm{D}+0.040 \mathrm{AB}+ \\
0.006 \mathrm{AD}-0.088 \mathrm{~A}^{2}-0.033 \mathrm{~B}^{2}-0.066 \cdot \mathrm{C}^{2}-0.113 \mathrm{D}^{2}
\end{gathered}
$$

Equation 2 gives the level of fructose amount as a function of the investigated factors affecting the hydrolysis process. The terms that do not contribute significantly to the prediction of $\mathrm{Y}$ were omitted from the full model and a reduced secondorder polynomial equation was obtained. This implies that the effect of hydrolysis time is significant as it is obvious from the high coefficient. The results of multiple linear regression analysis (reduced model) reveal that, by increasing the values of positive factors, the amount of fructose (expressed by Y) will increase.

Figure 2 depicts the interactions and the levels of the studied variables that are determined by plotting the response surface curves.

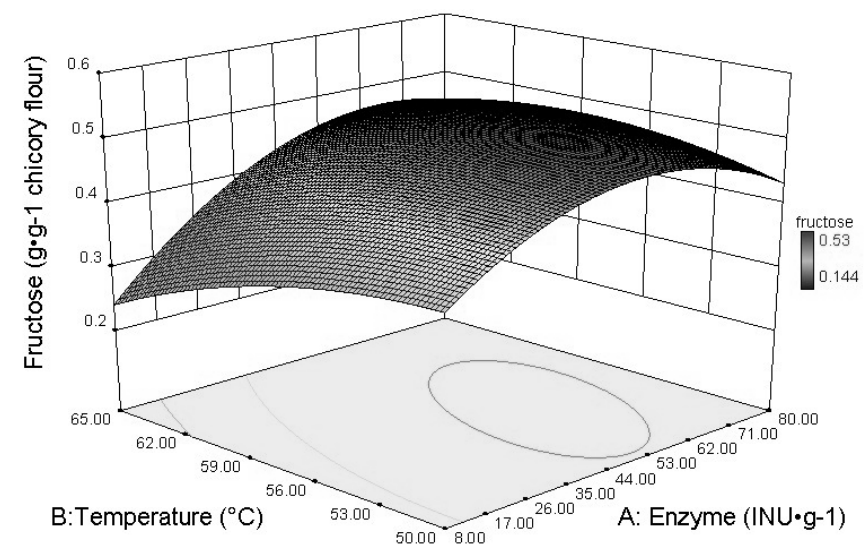

Figure 2. Response surface for enzymatic hydrolysis of chicory flour as a function of the enzyme concentration and temperature.

High production amount of fructose was observed at a temperature range of 51-61 ${ }^{\circ} \mathrm{C}$ and an enzyme concentration between 40 and $71 \mathrm{INU} \cdot \mathrm{g}^{-1}$, maintaining the hydrolysis time at 48.5 hours and the $\mathrm{pH}$ value at 5.25.

In Figure 3, for constant values of temperature $\left(57.5^{\circ} \mathrm{C}\right)$ and hydrolysis time (48.5 hours), the fructose amount produced is maximum for a $\mathrm{pH}$ range between 4.9 and 5.7 and an enzyme concentration between 40 and $71 \mathrm{INU} \cdot \mathrm{g}^{-1}$.

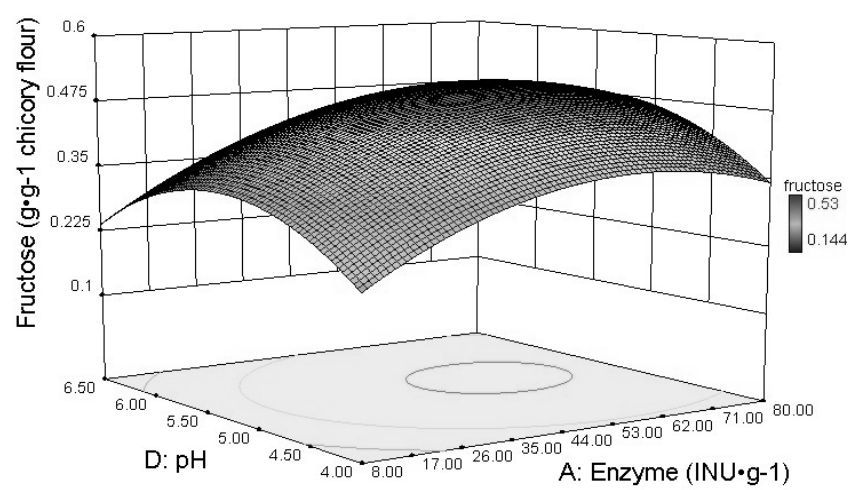

Figure 3. Response surface for enzymatic hydrolysis of chicory flour as a function of the enzyme concentration and $\mathbf{p H}$.

We used the Design-Expert software for the numerical optimization of fructose amount produced by enzymatic hydrolysis. Maintaining the hydrolysis time at 96 hours of hydrolysis, the $\mathrm{pH}$ at 5.26 and maximizing the values of temperature and enzyme concentration, Design-Expert software showed in figure 3 the maximum fructose amount $\left(0.55 \mathrm{~g} \cdot \mathrm{g}^{-1}\right.$ chicory flour) for a desirability of 0.952 .

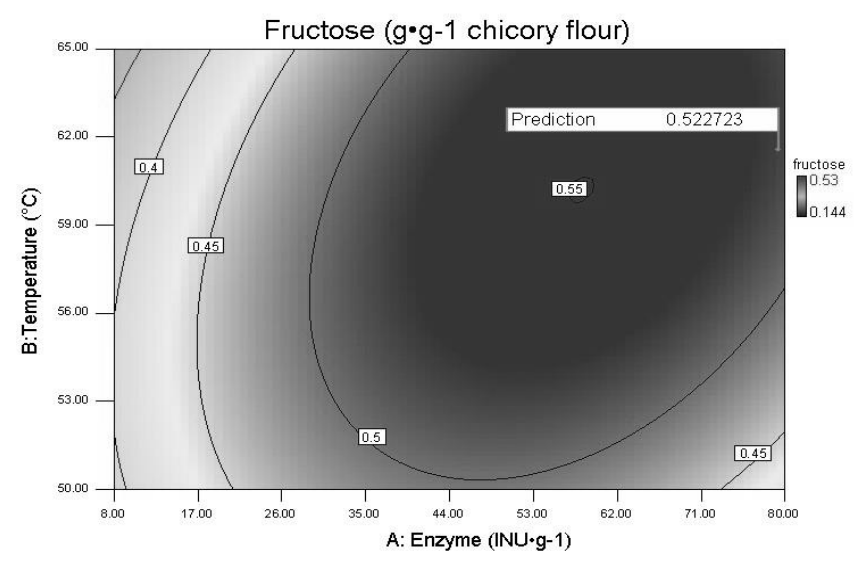

Figure 4. Contour plot for fructose amount optimization.

For the temperature between $60-61{ }^{\circ} \mathrm{C}$ and for an enzyme concentration between 56 and $60 \mathrm{INU} \cdot \mathrm{g}^{-1}$, the maximum amount of fructose is $0.55 \mathrm{~g} \cdot \mathrm{g}^{-1}$ chicory flour.

The increasing fructose amount indicates that the commercial inulinase acts at the end of the polymer chain, the enzyme having an exo-inulinase activity.

Complete hydrolysis of inulin with inulinase may lead to a final mass fraction of fructose of $95 \%$ when performed under optimized conditions, according to de Lima (2010). Our fructose hydrolysis yield using Aspergillus niger inulinase is $79.6 \%$, closed to the inulin hydrolysis yield of $77.9 \%$ produced by Liu (2010).

The maximum fructose yield for pure inulin hydrolysis by the microbial exo-inulinases is between $95-98 \%$, as many 
researchers have found (Pandey et al., 1999; Ricca et al., 2007; Singh et al., 2006).

Our hydrolysis parameters are in accordance with those obtained by other researchers which reported the significant parameters for inulin hydrolysis using the statistical analysis. Rocha (2005), established, by factorial design and surface response methodology, the optimal conditions for inulin hydrolysis using a commercial free and immobilised inulinase produced by Aspergillus niger. The model system estimated optimal $\mathrm{pH}$ and temperature values of 5.4 and $52{ }^{\circ} \mathrm{C}$ for the immobilised inulinase and of 4.9 and $56{ }^{\circ} \mathrm{C}$ for the free inulinase.

Conclusions: The enzymatic hydrolysis conditions for chicory fructans using commercial fungal inulinase were optimised by applied statistical optimisation and response surface methodology. The hydrolysis time, the enzyme concentration and the hydrolysis $\mathrm{pH}$ have significant influence on the yield of hydrolysis. The temperature has an insignificant effect on fructose releasing from fructans hydrolysis. By using hydrolysis temperature between 60 and $61{ }^{\circ} \mathrm{C}$ and enzyme concentration between 56 and $60 \mathrm{INU} \cdot \mathrm{g}^{-1}$ and maintaining the hydrolysis time at 96 hours and the $\mathrm{pH}$ at 5.26 , high fructans hydrolysis yield can be achieved. The mathematical optimisation of enzymatic hydrolysis process assures a good opportunity to increase the efficiency of biotechnological conditions for polymer bioconversion in simple sugars by evaluation of the correlative effect of different factors.

Acknowledgement: This work has benefited from financial support through the 2010 POSDRU/89/1.5/S/52432 project "Organizing the national interest postdoctoral school of Applied biotechnologies with impact on Romanian bioeconomy", project co-financed by the European Social Fund through the Sectoral Operational Programme Human Resources Development 2007-2013.

\section{REFERENCES}

AOAC. 2003. Official Methods of Analysis of AOAC International, $17^{\text {th }}$ Ed. Tech. Rep. Gaithersburg, MD, USA.

Chen, X.M., X.M. Xu, Z.Y. Jin and H.Q. Chen. 2012. Expression of an endoinulinase from Aspergillus ficuum JNSP5-06 in Escherichia coli and its characterization. Carbohyd. Polym. 88:748-753.

Chi, Z.M., T. Zhang, T.S. Cao, X.Y. Liu, W. Cui and C.H. Zhao. 2011. Biotechnological potential of inulin for bioprocesses. Bioresour. Technol. 102:4295-4303.

Cruz, V.D., J.G. Belote, M.Z. Belline and R. Cruz. 1998. Production and action pattern of inulinase from Aspergillus Niger-245: Hydrolysis of inulin from several sources. Rev. Microbiol. 29:301-306. de Lima, C.J.B., L.F. Coelho and J. Contiero. 2010.The use of response surface methodology in optimization of lactic acid production: Focus on medium supplementation, temperature and $\mathrm{pH}$ control. Food Technol. Biotechnol. 48:175-181.

Esbensen, K.H. 2010. Multivariate Data Analysis- In Practice, $5^{\text {th }}$ Ed. Alborg University, Esbjerg.

Hodgins, K.A., Z. Lai, L.O. Oliveira, D.W. Still, M. Scascitelli, M.S. Barker, N.C. Kane, H. Dempewolf, A. Kozik, R.V. Kesseli, J.M. Burke, R. W.Michelmore and J.M. Burke. 2014. Genomics of Compositae crops: reference transcriptome assemblies and evidence of hybridization with wild relatives. Mol. Ecol. Resour. 14:166-177.

Lima, D.M., P. Fernandes, D.S. Nascimento, R. de C.L.F. Ribeiro and S.A. Assis. 2011. Fructose syrup: a biotechnology asset. Food Technol. Biotechnol. 49:424434.

Liu, X.Y., Z. Chi, G.L. Liu, F. Wang, C. Madzak and Z.M. Chi. 2010. Inulin hydrolysis and citric acid production from inulin using the surface-engineered Yarrowia lipolytica displaying inulinase. Metab. Eng. 12:469-476.

Miller, G.L. 1959. Use of dinitrosalicylic acid reagent for determination of reducing sugar. Anal. Chem. 31:426428.

Muir, J.G., S.J. Shepherd, O. Rosella, R. Rose, J.S. Barrett and P.R. Gibson. 2007. Fructan and free fructose content of common Australian vegetables and fruit. J. Agric. Food Chem. 55:6619-6627.

Pandey, A., C.R. Soccol, P. Selvakumar, V.T. Soccol, N. Krieger and J.D. Fontana. 1999. Recent developments in microbial inulinases. Appl. Biochem. Biotechnol. 81:3552.

Ricca, E., V. Calabro, S. Curcio and G. Iorio. 2007. The state of the art in the production of fructose from inulin enzymatic hydrolysis. Crit. Rev. Biotechnol. 27:1-17.

Rocha, J.R., R. Catana, B.S. Ferreira, J.M. Cabral and P. Fernandes. 2005. Design and characterization of an enzyme system for inulin hydrolysis. Food Chem. 95: 7782.

Singh, P. and P.K. Gill. 2006. Production of inulinases: Recent advances. Food Technol. Biotechnol. 44:51-162.

Sirisansaneeyakul, S., N. Worawuthiyanan, W. Vanichsriratana, P. Srinophakun and Y. Chisti. 2007. Production of fructose from inulin using mixed inulinases from Aspergillus niger and Candida guilliermondii. World J. Microbiol. Biotechnol. 23:543552.

Trivedi, S., J. Divecha and A. Shah. 2012. Optimization of inulinase production by a newly isolated Aspergillus tubingensis CR16 using low cost substrates. Carbohyd. Polym. 90:483-490.

Wang, Q. and J. Cui. 2011. Perspectives and utilization technologies of chicory (Cichorium intybus L.): A review. Afr. J. Biotechnol. 10:1966-1977. 